\title{
Phylogenetic analysis of deformed wing virus, black queen cell virus and acute bee paralysis viruses in Turkish honeybee colonies
}

\author{
ABDURRAHMAN ANIL CAGIRGAN, YAKUP YILDIRIM*, AYSEGUL USTA* \\ Department of Virology, Izmir/Bornova Veterinary Control Institute, 35040, Bornova, Izmir, Turkey \\ *Department of Virology, Faculty of Veterinary Medicine, Burdur Mehmet Akif Ersoy University, 15100, Burdur, Turkey
}

\section{Cagırgan A. A., Yildirim Y., Usta A.}

Phylogenetic analysis of deformed wing virus, black queen cell virus and acute bee paralysis viruses in Turkish honeybee colonies

\section{Summary}

Viruses are chiefly responsible for colony losses globally, and deformed wing virus (DWV), black queen cell virus $(\mathrm{BQCV})$, and acute bee paralysis virus (ABPV) are the most common viral infections in honeybee colonies. As Turkey ranks third in the world in terms of bee colonies, honeybees are of great ecological and economic importance. Thus, the aim of this study was to conduct a phylogenetic analysis of DWV, BQCV, and ABPV, all of which were detected in the southern city of Burdur, which is located along the route that migratory bees take and is a dwelling place for them. Phylogenetic trees were constructed for DWV, BQCV, and ABPV partial nucleotide sequences of the RNA helicase region, the structural polypeptide coding region, and the capsid protein region, respectively. Burdur DWV1 and DWV14 isolates were highly conserved, with 99-100\% similarity, and they also shared $93-100 \%$ similarity with isolates from Europe and Korea. The two Burdur DWVs had 98\% similarity. The DWV1 genome was more similar to the other Turkish isolates than the DWV14. Burdur BQCV2 and BQCV19 isolates, which were highly conserved with $\mathbf{9 7 - 9 9 \%}$ similarity, formed the same cluster with other Turkish isolates but excluding the Turkey Koycegiz isolate. Burdur ABPV isolates were highly conserved with $\mathbf{9 9 \%}$ similarity. Although they showed $94-97 \%$ similarity with other European isolates, they were in the same cluster as Turkish isolates. Thus, it was found that although the DWV, BQCV, and $A B P V$ isolates obtained as a result of the present study were highly conserved, they showed differences in relation to the DWV, BWCV, and ABPV isolates that were isolated from different geographical regions.

Keywords: phylogenetic analysis, deformed wing virus, black quenn cell virus, acute bee paralysis virus, Turkey

Honeybees are the most important pollinators for food plants and flowering plants; and therefore they are indispensable for agricultural food cultivation and ecological balance (28). Unfortunately, great losses have recently been observed in honeybee populations $(1,20)$. There was a loss of approximately 10 million bees in the United States in the winter of 2006-2007 when a factor causing the sudden disappearance of all adult bees in a hive caused colony collapse disorder (CCD) in honeybees (11). It is believed that the reduction in honeybee populations is caused by parasitic diseases, genetic factors, severe seasonal weather conditions, malnutrition, and exposure to pesticides $(13,27)$. In addition, it is known that colony losses are caused by viruses that adversely affect bee health $(10,45)$.
The field of bee viral ecology has expanded dramatically since the detection of the first honeybee virus in $1913(8,46)$. So far, more than 24 bee viruses have been detected. Most of them are single-stranded, positive-sense RNA viruses of the Picornaviridae family $(6,8)$. The Picornaviridae family include the common bee viruses of the Dicistroviridae family, such as Israeli acute paralysis virus (IAPV), kashmir bee virus (KBV), acute bee paralysis virus (ABPV), black queen cell virus (BQCV) as well as viruses of the Iflaviridae family, such as deformed wing virus (DWV), kakugo virus, varroa destructor virus-1/DWV-B, sacbrood virus (SBV), and slow bee paralysis virus (22).

So far, DWV has been the most frequently detected bee virus in honey bees $(9,21,33,36,37)$. It is a non- 
enveloped virus of the Iflaviridae family with a linear genome of approximately $9-11 \mathrm{~kb}$ (44). DWV is transmitted to the host vertically (from the queen to the offspring) and horizontally via trophallaxis and shared food resources. The viral load and virulence of DWV are also important for infection $(7,49)$. One of the important transmission sources of the agent is Varroa destructor. It is already known that there is a positive correlation between varroa infestation and DWV in bee colonies $(4,31)$.

ABPV is a non-enveloped virus of the Aparavirus genus of the Dicistroviridae family. Its diameter is $30 \mathrm{~nm}$. It has a single-stranded linear, positive-sense RNA genome of 8-10 kb (43). After 5-6 days of incubation, tremors in the body and wing, paralysis and sudden deaths occur in bees (8). Varroa destructor plays an important role in the transmission of ABPV as a vector (41). In addition to horizontal transmission, the agent can also be transmitted vertically (48).

BQCV is a non-enveloped virus of the Triatovirus genus of the Dicistroviridae family. Its diameter is $30 \mathrm{~nm}$. It has a single-stranded linear RNA genome with a length of 8-10 kb and positive polarity (39). BQCV affects mostly developing queen larvae and pupae in the capped-cell stage. BQCV readily multiplies in the pupal stage. Infected pupae turn dark brown to black along with the walls of the cell, and quick deaths occur (32). It is known that the disease increases in spring and summer (2). The agent spreads horizontally and vertically (7). Although disease outbreaks are frequently associated with Noesama apis (5), it is believed that the transmission of BQCV is also due to Varroa destructor (41).

As Turkey ranks third in the world in terms of its number of bee colonies and second in terms of honey production (12), honeybees are of great ecological and economic importance. Although there have been numerous colony losses throughout the world, the reasons for which are mainly unknown, one of the principal factors that leads to colony loss is viruses. For this reason, bee viruses have been the subject of many different studies conducted in Turkey $(14,17$, $18,23,35,42$ ).

The aim of this study was to conduct a phylogenetic analysis of DWV, BQCV, and ABPV and determine their molecular characterizations in the southern city of Burdur, which is located along the route that migratory bees take and is a dwelling place for them.

\section{Material and methods}

Collection of the samples. The sampling of the present study was carried out to determine the molecular characterisation and phylogenetics of $\mathrm{ABPV}, \mathrm{BQCV}$, and DWV, all of which are bee viruses in the Burdur region of Turkey. A total of 30 samples (each sample consists of 30 adult bees) were taken randomly from 15 apiaries in the city of Burdur and its surrounding villages: namely, Karaçal, Kumruca, Akyaka, Yazköy, and Çentik. The adult bee samples were brought to the laboratory under cold chain storage.
Tab. 1. Primers for sequencing

\begin{tabular}{|l|l|c|c|}
\hline \multicolumn{1}{|c|}{ Agent } & \multicolumn{1}{|c|}{ Primers } & $\begin{array}{c}\text { Amplicon } \\
\text { length }\end{array}$ & References \\
\hline $\begin{array}{l}\text { DWV HP-F } \\
\text { DWV HP-R }\end{array}$ & $\begin{array}{l}\text { CCACATGGTCTGAATGGATGACG } \\
\text { CACGACGCTTACTACACCAC }\end{array}$ & 618 bp & 30 \\
$\begin{array}{l}\text { ABPV CP-F } \\
\text { ABPV CP-R }\end{array}$ & $\begin{array}{l}\text { TTATGTGTCCAGAGACTGTATCCA } \\
\text { GCTCCTATTGCTCGGTTTTTCGGT }\end{array}$ & 900 bp & 34 \\
$\begin{array}{l}\text { BQCV-F } \\
\text { BQCV-R }\end{array}$ & $\begin{array}{l}\text { TGCAACCTCCTACGAACTCT } \\
\text { TCCATGGCGACAGTTACATC }\end{array}$ & 514 bp & 40 \\
\hline
\end{tabular}

Preparation of the samples and RNA extraction. A pool consisting of 30 adult bees was created for each apiary. These pools were homogenised with $5 \mathrm{ml}$ of Eagle's Minimum Essential Medium (Sigma Aldrich, United Kingdom). Next, the homogenates were centrifuged at $5000 \mathrm{rpm}$ at $4^{\circ} \mathrm{C}$ for 30 minutes. Following this, $200 \mu \mathrm{l}$ was taken from the supernatant obtained after the centrifuging of the homogenates for RNA extraction. This was carried out using the High Pure Viral RNA Kit (Roche, Germany) in accordance with the manufacturer's instructions. The extracted RNA was stored at $-80^{\circ} \mathrm{C}$ until the analysis began.

RT-PCR. The RNA was then used for reverse transcription polymerase chain reaction (RT-PCR) amplification. The specific primers used for the amplification are shown in Table 1. The Xpert One-Step RT-PCR Kit (Grisp Research Solutions, Porto, Portugal) was used for the amplification. The total reaction volume was $25 \mu \mathrm{l}$, and the final concentration of the primer was $0.4 \mathrm{mM}$.

The termal cycling conditions consisted of one cycle at $45^{\circ} \mathrm{C}$ for 15 minutes for reverse transcription followed by initial denaturation at $95^{\circ} \mathrm{C}$ for 3 minutes. This was followed by denaturation at $95^{\circ} \mathrm{C}$ for 10 seconds, annealing at $55^{\circ} \mathrm{C}$ for DWV and BQCV for 10 seconds, and annealing at $54^{\circ} \mathrm{C}$ for ABPV for 10 seconds, and finally an extension at $72^{\circ} \mathrm{C}$ for 15 seconds for 35 cycles, with a final extension at $72^{\circ} \mathrm{C}$ for 1 minute.

The PCR products were run in TAE Buffer with $1.5 \%$ agarose gel containing ethidium bromide. Then, the RT-PCR gel images were evaluated using a UV transilluminator.

Nucleotide sequence analysis and phylogenetic analysis. The PCR products were sequenced as Forward and Reverse directions by Microsynth AG (Balgach, Switzerland). The nucleotide sequence results were assembled and edited using DNADynamo DNA Sequence Analysis Software. The consensus nucleotide sequences were verified using the Basic Local Alignment Search Tool at the National Center for Biotechnology Information.

The consensus sequences of the DWV, ABPV, and BQCV viruses obtained were used for phylogenetic analysis. The multiple sequence alignments of the data were performed using the ClustalW algorithm. The multiple sequence alignments of the consensus sequences and reference sequences obtained from the GenBank sequence database were conducted using the ClustalW Algorithm. Next, the best DNA/ protein models were identified for use in phylogeny. Phylogenetic trees were constructed using the latest version of the Molecular Evolutionary Genetics Analysis software (MEGA7) with the neighbor-joining (NJ) method and Tamura's 3-parameter and the Tamura-Nei parameter. The best substitution models were selected for each tree, and a bootstrap value of 1,000 was replicated for all methods. 


\section{Results and discussion}

The results revealed the presence of DWV and ABPV in 13 out of 15 apiaries, and BQCV in 8 out of 11 apiaries. A sequence analysis was carried out on two of the adult bee samples that were identified as DWV-positive. A phylogenetic analysis was carried out by sequencing $484 \mathrm{bp}$ (6129-6613) of the gene coding region to create a helicase protein of DWV. A total of 34 sequences obtained from the GenBank database and reported in previous studies were used. The TN93+I Model (Tamura-Nei) was determined as the best DNA/protein model $(19,25)$. The phylogenetic tree that was created using the NJ method is showed in Figure 1. According to the data obtained, $98 \%$ similarity was determined between the Burdur DWV1 and Burdur DWV14 isolates. The Cine (MK431870), Soke (MK431871), Koycegiz (MK431873), and Seydikemer (MK431874)

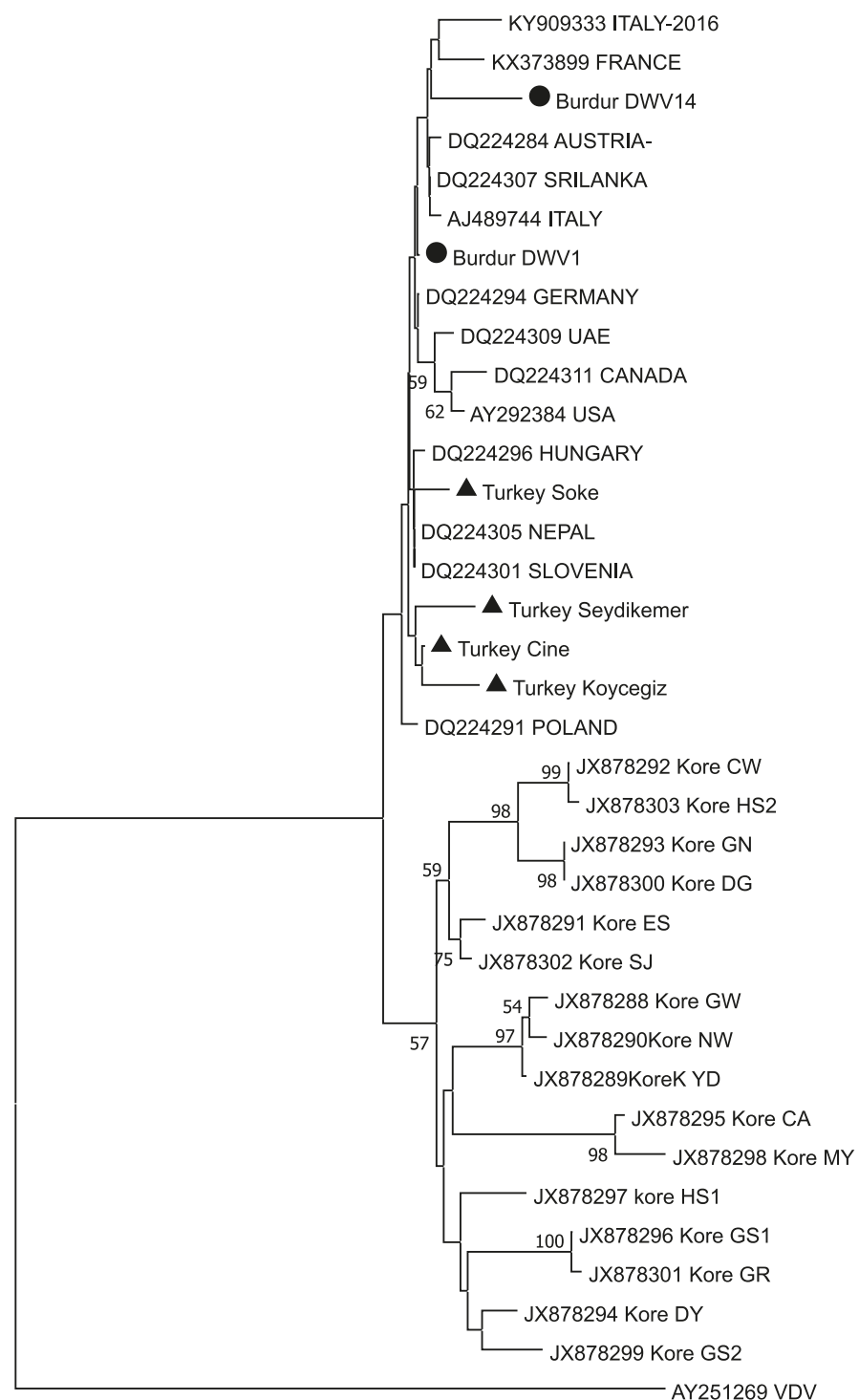

0.02

Fig. 1. Neighbor-joining tree based on the partial helicase gene region (ORF1) of DWV from Turkey and other countries. The isolates were aligned by the ClustalW, and the phylogenetic tree was constructed using the MEGA 7 package with a bootstrap value of 1.000 replicates.
DWV isolates in the Genbank database showed 99$-100 \%$ similarity to the DWV1 isolate, and the DWV14 isolate showed $98 \%$ similarity. It was also determined that Burdur isolates were similar to European isolates at 98-100\% similarity and were similar to Korean isolates at $93-96 \%$ similarity.

A sequence analysis was performed on one of the samples identified as ABPV-positive. The analysis revealed a sequence of a $796 \mathrm{bp}$ (8526-9323) in the gene region of the capsid protein. A total of 18 sequences obtained from the GenBank database and mentioned in previous studies were used. The sequences were aligned using MEGA7 software, and the T92+G Model (Tamura-3) was determined as the best DNA/protein model $(19,25)$. The phylogenetic tree was created using the NJ method (Fig. 2). The ABPV isolate that was obtained showed similarity with the Koycegiz (MK431884), Odemis (MK431885), and Fethiye (MK431886) isolates found

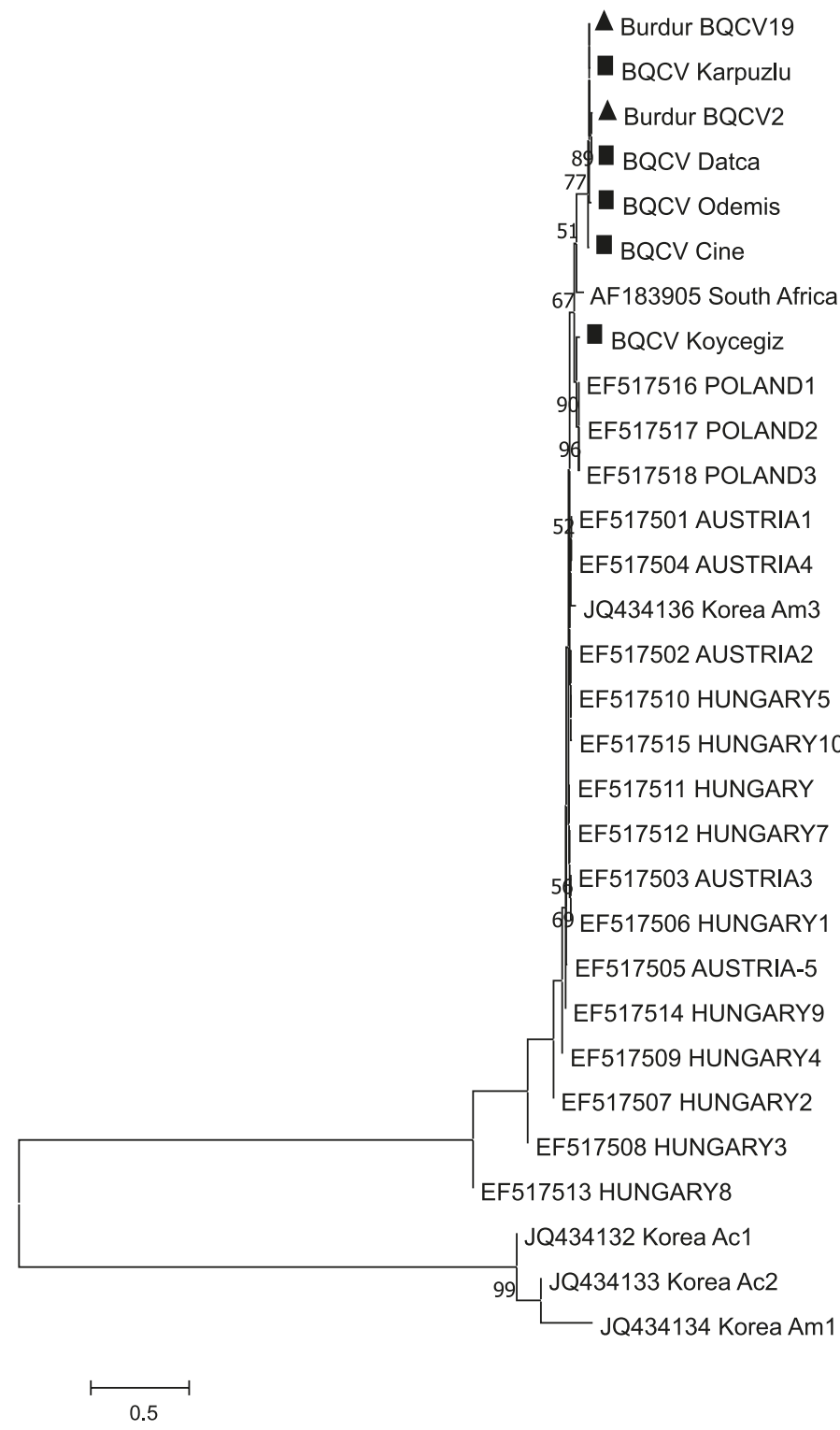

Fig. 2. Neighbor-joining tree based on the partial structural polypeptide coding region (ORF2) of BQCV from Turkey and other countries. The isolates were aligned by the ClustalW, and the phylogenetic tree was constructed using the MEGA 7 package with a bootstrap value of 1.000 replicates. 
in the Genbank database at $99 \%$ similarity. It also showed $94-97 \%$ similarity to European isolates, $94 \%$ to South African isolates, $92 \%$ to American isolates, and $80-81 \%$ to Chile, Brazilian, and Uruguayan isolates.

A sequence analysis was conducted on two of the samples identified as BQCV-positive. As a result of the sequence analysis, a sequence of 383 bp (6614-6996) was obtained from the gene coding of a structural polyprotein of BQCV. A total of 28 sequences obtained from the GenBank database and reported in previous studies were used. The T92+G Model (Tamura-3) was determined as the best DNA/protein model $(19,25)$. The phylogenetic tree shown in Figure 3 was created using the NJ method. The similarity of the Burdur isolates BQCV2 and BQCV19 were similar to each other, with 98\% similarity. However, the BQCV Turkey isolates from Cine (MK431878), Datca (MK431879), Karpuzlu (MK431881), and Odemis (MK431883) showed 97$-99 \%$ similarity, and the similarity with the Köycegiz (MK431880) isolate was determined to be $90 \%$. The Korean Am3 isolate, which was obtained from Korean Apis mellifera, was identified as being in the same branch as the European and Korean BQCV isolates, which were isolated from Apis cerana and placed in a different branch on the tree.

Turkey has the largest beekeeping industry in the world and is an important country that connects Asia, the Middle East, and Europe. It has approximately 7.5 million bee colonies, and 107,000 tons of honey are produced annually (12). However, a major problem in relation to beekeeping in Turkey is colony loss. It has been found that globally, viruses are chiefly responsible for colony loss $(6,11,16,38)$.

Numerous studies have been performed on bee viruses in Turkey in the past $(14,17,18,23,35,42)$. In these studies, it was reported that the incidence of DWV was high in certain regions in Turkey $(24,42)$. However, only a limited number of studies have focused on the phylogenetics of DWV. In a study that targeted different gene regions (18), it was determined that the isolates obtained from eastern Turkey (the Van province) were similar to the isolates from England, Denmark, and Italy with $98-100 \%$ similarity. In this study, sequence analyses and phylogenetic analyses were performed by targeting the region that encoded the DWV helicase gene. According to the data obtained in this study, Cine, Soke, Seydikemer, and Köycegiz DWV isolates in the Genbank database and Burdur DW1 showed 99-100\% similarity, and Burdur DWV14 isolate showed 98\% similarity. It was also found in the present study that Korean isolates constituted a separate cluster. This can be explained by the genetic recombination that occurs between Korean DWV genotypes and various country genotypes (30). A similar situation was also noted in foot and mouth disease serotypes (15) and in Israeli acute paralysis virus genotypes (29). In their study, Yang et al. (47) targeted the gene that encoded the capsid protein, and the American, Chinese, and Japanese genotypes formed a different cluster. For this reason, DWV

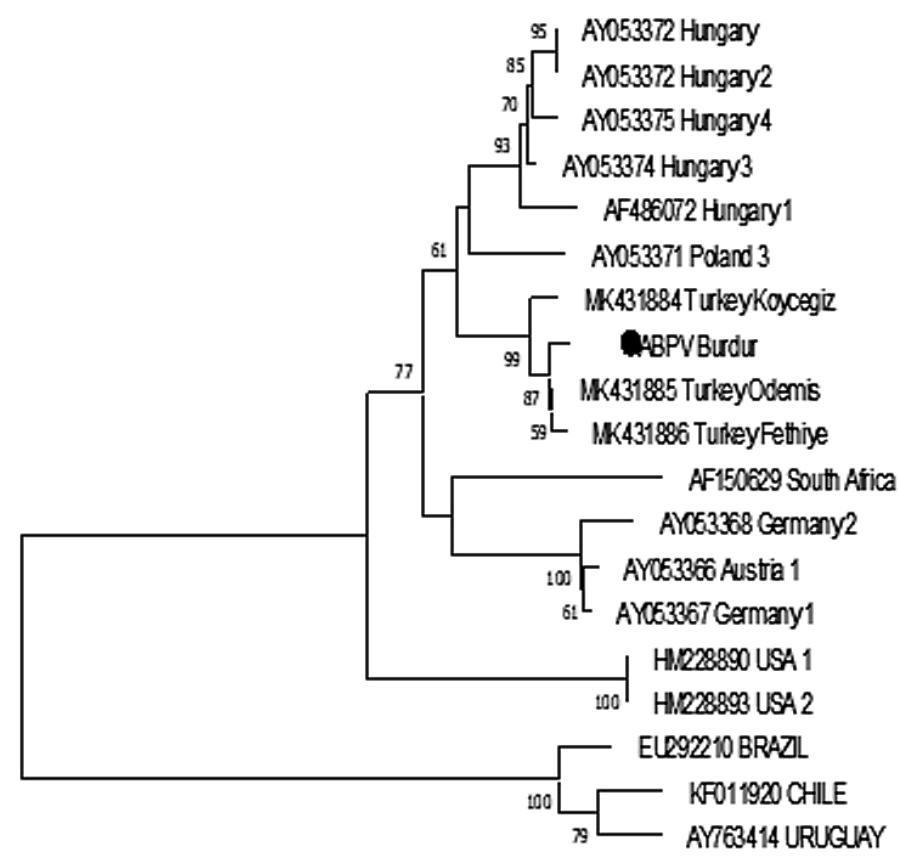

Fig. 3. Neighbor-joining tree based on the partial structural capsid protein coding regions of $\mathrm{ABPV}$ from Turkey and other countries. The isolates were aligned by the ClustalW, and the phylogenetic tree was constructed using the MEGA 7 package with a bootstrap value of 1.000 replicates.

genotypes detected in different geographical regions are considered prone to different genetic variations.

$\mathrm{BQCV}$ is one of the most common bee viruses in Turkey (14). The molecular characterisation of BQCV was created for the first time in Turkey using trBQCV isolates obtained from apiaries that suffered colony losses in different regions of Turkey between 2007-2013. The differences between Turkish isolates were identified by targeting the helicase gene region and the structural capsid gene region (23). Although the gene region that encodes the helicase gene is more variable compared to the gene region that encodes the capsid protein at the nucleotide level, it is partially preserved at the amino-acid level. In this study, the less-variable structural capsid gene region was targeted, and it was determined that the isolates in the same geographical regions showed similarities. However, the Korean Am3 isolate was found to be in the same cluster as the European isolates, similar to the study conducted by Noh et al. (26). The Turkish Koycegiz isolate showed 90\% similarity with other Turkish isolates. It is possible to observe genetic diversity and mutations in gene regions that are protected in field isolates (23). In addition, the possibility of recombining virus genotypes in the Picornaviridae family of BQCV was also considered in this respect $(26,40)$.

The nucleotide sequence of Burdur ABPV isolate showed high similarity (99\%) with Turkish isolates. Bakonyi et al. (3) reported that German and Austrian isolates formed one group and that the Hungarian isolate formed another group, with Polish isolates showing variations. The present study was conducted by targeting the capsid gene region, and the findings obtained were parallel with the study conducted by Rodriguez et al. 
(34). It was reported in previous studies that the isolates in similar geographical regions were similar, which can be explained by the fact that the capsid protein is a protected region and therefore not prone to genetic diversity and mutation.

\section{References}

1. Aizen M. A., Harder L. D.: The global stock of domesticated honey bees is growing slower than agricultural demand for pollination. Curr. Biol. 2009, 19 , 915-918

2. Bailey L., Ball B. V., Perry J. N.: The prevalence of viruses of honey bees in Britain. Ann. Appl. Biol. 1981, 97, 109-118.

3. Bakonyi T., Frakas R., Szendroi A., Dobos-Kovacs M., Rusvai M.: Detection of acute bee paralysis virus by RT-PCR in honey bee and Varroa destructor field samples: rapid screening of representative Hungarian apiaries. Apidologie 2002 , 33, 63-74

4. Barroso-Arévalo S., Fernández-Carrión E., Goyache J., Molero F., Puerta F Sánchez-Vizcaíno J. M.: High Load of Deformed Wing Virus and Varroa destructor Infestation Are Related to Weakness of Honey Bee Colonies in Southern Spain. Front. Microbiol. 2019, 10, 1331

5. Berényi O., Bakonyi T., Derakhshifar I., Köglberger H., Nowotny N.: Occurrence of six honeybee viruses in diseased Austrian apiaries. Appl. Environ. Microbiol. 2006, 72, 2414-2420.

6. Brutscher L. M., McMenamin A. J., Flenniken M. L.: The buzz about honey bee viruses. PLOS Pathog. 2016, 12, e1005757.

7. Chen Y., Evans J., Feldlaufer M.: Horizontal and vertical transmission of viruses in the honey bee, Apis mellifera. J. Invertebr. Pathol. 2006, 92, 152-159.

8. Chen Y., Siede R.: Honey bee viruses. Adv. Virus Res. 2007, 70, 33-80.

9. Cirkovic D., Stevanovic J., Glavinic U., Aleksic N., Djuric S., Aleksic J., Stanimirovic Z.: Honey bee viruses in Serbian colonies of different strength. Peer J. 2018, DOI: 10.7717/peerj.5887.

10. Cornman R. S., Tarpy D. R., Chen Y, Jeffreys L., Lopez D., Pettis J. S. vanEngelsdorp D., Evans J. D.: Pathogen webs in collapsing honey bee colonies. PLoS ONE. 2012, 7, e43562.

11. Cox-Foster D. L., Conlan S., Holmes E. C., Palacios G., Evans J. D., Moran N. A., Quan P. L., Briese T., Hornig M., Geiser D. M., Martinson V., VanEngelsdorp D., Kalkstein A. L., Drysdale A., Hui J., Zhai J. H., Cui L. W. Hutchison S. K., Simons J. F., Egholm M., Pettis J. S., Lipkin W. I.: A metagenomic survey of microbes in honey bee colony collapse disorder. Science 2007 , 318, 283-287.

12.Doğanay A., Girişgin A. O.: Genel Arıcılık (General beekeeping), [in:] Doğanay A., Aydın L. (ed.): Bal Arısı Yetiştiriciliği Ürünleri Hastalıkları (Honey bee breeding). $1^{\text {th }}$ ed., Dora Publications, Bursa 2017, 21-146.

13. Goulson D., Nicholls E., Botias C., Rotheray E. L.: Bee declines driven by combined stress from parasites, pesticides, and lack of flowers. Science 2015 $347,1255957$.

14. Gümüssova S., Albayrak H., Yazıcı Z., Kurt M.: Prevalence of three honey bee viruses in Turkey. Veterinarski Arhiv 2010, 80, 779-785

15. Heath L., van der Walt E., Varsani A., Martin D. P.: Recombination pattern in aphthoviruses mirror those found in other picornaviruses. J. Virol. 2006, 80, 11827-11832.

16. Highfield A. C., Nagar A. L, Mackinder L. C. M., Noël L., Hall M. J., Martin S. J., Schroeder D. C.: Deformed wing virus implicated in overwintering honeybee colony losses. Appl. Environ. Microbiol. 2009, 75, 7212-7220.

17. Kalayci G., Cagırgan A. A., Pekmez K., Ozkan B., Kaplan M.: Molecular detection and phylogenetic analysis of the honeybee (Apis mellifera) sacbrood virus in Turkey. Turk. J. Vet. Anim. Sci. 2019, 43, 551-554.

18. Karapınar Z., Ŏguz B., Dinçer E., Öztürk C.: Phylogenetic analysis of black queen cell virus and deformed wing virus in honeybee colonies infected by mites in Van, Eastern Turkey. Med. Weter. 2018, 74, 460-465.

19. Kumar S., Stecher G., Tamura K.: MEGA7: Molecular Evolutionary Genetics Analysis version 7.0 for bigger datasets. Molecular Biology and Evolution. 2016, 33, 1870-1874.

20. Levy S.: The pollinator crisis: What's best for bees. Nature 2011, 479, 164-165.

21. Locke B., Semberg E., Forsgren E., de Miranda J. R.: Persistence of subclinica deformed wing virus infections in honeybees following Varroa mite removal and a bee population turnover. PLoS ONE 2017, 12, e0180910.

22. McMenamin A., Flenniken M. L.: Recently identified bee viruses and their impact on bee pollinators. Curr. Opin. Insect. Sci. 2018, 26, 120-129.

23. Muz D., Muz N. M.: A molecular epidemiological study of black queen cell virus in honeybees (Apis mellifera) of Turkey: the first genetic characterization and phylogenetic analysis of field viruses. Apidologie 2017, 49, 1-12.

24. Muz D., Muz N. M.: Survey of the occurrence of Deformed Wing Virus and multiple parasites of queens (Apis mellifera L.) in apiaries with collapsed colonies in Hatay, Turkey. J. Apic. Res. 2009, 48, 204-208.

25. Nei M., Kumar S.: Molecular Evolution and Phylogenetics. Oxford University Press, New York.

26. Noh J. H., Reddy K. E., Choe S. E., Yoo M. S., Doan H. T., Kweon C. H., Ramya M., Yoon B. S., Nguyen L. T., Nguyen T. T., Van Quyen D., Jung S. C.,
Chang K. Y., Kang S. W: Phylogenetic analysis of black queen cell virus genotypes in South Korea. Virus Gene. 2013, 46, 362-368.

27. Potts S. G., Biesmeijer J. C., Kremen C., Neumann P., Schweiger O., Kunin W. E.: Global pollinator declines: Trends, impacts and drivers. Trends. Ecol. Evol. 2010, 25, 345-353.

28. Potts S. G., Petanidou T., Roberts S., O’Toole C., Hulbert A., Willmer P.: Plantpollinator biodiversity and pollination services in a complex Mediterranean landscape. Biol. Conserv. 2006, 129, 519-529.

29. Reddy K. E., Noh J. H., Kim Y. H., Yoo M. S., Doan H. T. T., Ramya M., Jung $S$. C., Quyen D. V., Kang $S$. W.: Analysis of the nonstructural and structural polyprotein regions, and complete genome sequences of Israil acute paralysis viruses identified from honeybees (Apis mellifera) in Korea. Virology 2013, 444, 211-217.

30. Reddy K. E., Noh J. H., Yoo M. S., Kim Y. H., Kim N. H., Doan H. T., Ramya M., Jung S. C., Van Quyen D., Kang S. W.: Molecular characterization and phylogenetic analysis of deformed wing viruses isolated from South Korea. Vet. Microbiol. 2013, 7, 167, 272-279.

31. Reyes-Quintana M., Espinosa-Montaño L. G., Prieto-Merlos D., Koleoglu G. Petukhova T., Correa-Benitez A., Guzman-Novoa E.: Impact of Varroa destructor and deformed wing virus on emergence, cellular immunity, wing integrity and survivorship of Africanized honey bees in Mexico. J. Invertebr. Pathol. 2019, 164, 43-48, doi: 10.1016/j.jip.2019.04.009.

32. Ribiere M., Ball B. V., Aubert M. F. A.: In Virology and the honey bee: Natural history and geographic distribution of honey bee viruses. 1. ed., EEC Publications, Luxembourg 2008, 15-84.

33. Roberts J. M. K., Anderson D. L., Durr P. A.: Absence of deformed wing virus and Varroa destructor in Australia provides unique perspectives on honeybee viral landscapes and colony losses. Sci. Rep. 2017, 7, 6925.

34. Rodríguez M., Vargas M., Antúnez K., Gerding M., Ovídio Castro F., Zapata N. Prevalence and phylogenetic analysis of honey bee viruses in the Biobío Region of Chile and their association with other honey bee pathogens. Chil. J. Agr. Res. 2014, 74, 170-177.

35. Rüstemoğlu M., Sipahioğlu H. M.: Occurrence and molecular characterization of acute bee paralysis virus (ABPV) in honeybee (Apis mellifera) colonies in Hakkari province. YYU. J. AGR. SCI. 2016, 26, 174-182.

36. Ryabov E. V., Fannon J. M., Moore J. D., Wood G. R., Evans D. J: The Iflaviruses Sacbrood virus and Deformed wing virus evoke different transcriptional responses in the honeybee which may facilitate their horizontal or vertical transmission. Peer J. 2016, 4, e1591.

37. Shumkova R., Neov B., Sirakova D., Georgieva A., Gadjev D., Teofanova D., Radoslavov G., Bouga M., Hristov P.: Molecular detection and phylogenetic assessment of six honeybee viruses in Apis mellifera L. colonies in Bulgaria. Peer J. 2018, doi: 10.7717/peerj.5077.

38. Simon-Delso N., Martin G. S., Bruneau E., Minsart L. A., Mouret C., Hautier L.: Honeybee colony disorder in crop areas: the role of pesticides and viruses. PLoS ONE. 2014, 9, e103073, doi:10.1371/journal.pone.0103073.

39. Spurny R., Pridal A., Palkova L., Kiema H. K. T., de Miranda J. R., Plevka P. Virion Structure of black queen cell virus, a common honeybee pathogen. J. Virol 2017, 91, e02100-16. pmid:28077635.

40. Tapaszti Z., Forgách P., Kovágó C., Topolska G., Nowotny N., Rusvai M., Bakonyi T.: Genetic analysis and phylogenetic comparison of black queen cell virus genotypes. Vet. Microbiol. 2009, 18, 139, 227-34

41. Tentcheva D., Gauthier L., Zappulla N., Dainat B., Cousserans F., Colin M. E., Bergoin M.: Prevalence and seasonal variations of six bee viruses in Apis mellifera L. and Varroa destructor mite populations in France. Appl. Environ. Microbiol. 2004, 70, 7185-7191.

42. Tozkar C. O., Kence M., Kence M., Huang Q., Evans J. D.: Metatranscriptomic analyses of heney bee colonies. Front. Genet. 2015, doi: 10.3389/ fgene.2015.00100

43. Valles S. M., Chen Y. P., Firth A. E., Guerin D. M. A., Hashimoto Y., Herrero S. de Miranda J. R., Ryabov E. \& ICTV Report Consortium: ICTV virus taxonomy profile: dicistroviridae. J. Gen. Vir. 2017, 98, 355-356.

44. Valles S. M., Chen Y. P., Firth A. E., Guerin D. M. A., Hashimoto Y., Herrero S. de Miranda J. R., Ryabov E. \& ICTV Report Consortium: ICTV virus taxonomy profile: iflaviridae. J. Gen. Vir. 2017, 98, 527-528.

45. Vanbergen A. J.: Insect Pollinators Initiative. Threats to an ecosystem service: Pressures on pollinators. Front. Ecol. Environ. 2013, 11, 251-259.

46. White G. F.: Sacbrood, a Disease of Bees.Washington, DC: US Dep Agric. 1913

47. Yang B., Peng G., Li T., Kadowaki T.: Molecular and phlylogenetic characterization of honey bee viruses, Nosema microsporidia, protozoan parazites and parasitic mites in China. Ecol. Evol. 2013, 3, 298-311.

48. Yue C., Schröder M., Bienefeld K., Genersch E.: Detection of viral sequences in semen of honeybees (Apis mellifera): evidence for vertical transmission of viruses through drones. J. Invertebr. Pathol. 2006, 92, 105-108.

49. Yue C., Schroder M., Gisder S., Genersch E.: Vertical-transmission routes for deformed wing virus of honeybees (Apis mellifera). J. Gen. Virol. 2007, 88, 2329-2336.

Corresponding author: Abdurrahman Anıl Çağırgan, DVM, PhD, Bornova/Izmir Veterinary Control Institute, Department of Virology, Bornova, Izmir, Turkey; e-mail: a.anilcagirgan@gmail.com 